\title{
Quality of Services and Satisfaction of Customer:Mediated by Consumer Buying Decision
}

\author{
Sikander Ali Qalati ${ }^{*}$ Li Wen Yuan ${ }^{1} \quad$ Shuja Iqbal $^{2} \quad$ Hamdaoui Hind $^{3}$ Rana Yassir Hussain ${ }^{2}$ \\ 1.School of Management, Department of Marketing, Jiangsu University, 301 Xuefu Road, Jingkou District, \\ Zhenjiang, Jiangsu, P.R. China. \\ 2.School of Management, Department of Management, Jiangsu University, 301 Xuefu Road, Jingkou District, \\ Zhenjiang, Jiangsu, P.R. China. \\ 3.School of Mechanical Engineering, Department of Mechanical, Jiangsu University, 301 Xuefu Road, Jingkou \\ District, Zhenjiang, Jiangsu, P.R. China.
}

\begin{abstract}
During era of 1990s, Paktel enjoyed the profits and hold market in a hand. As time goes on other providers entered into the market. Than rivalry was increased due to the saturated market. This conditions benefitted customers and put them in myth of to whom they select as their basic service providers. This study conducted with the aim to investigate the influence of quality of services $\mathrm{QoS}$ and role of family and friends $\mathrm{F} \& \mathrm{~F}$, on consumer buying decision CBD and satisfaction of customers SoC. 567 responses collected via field survey. The techniques of bootstrapping, PLS Algorithms, and structural equation modeling was used. Findings involve CBD positively and significantly mediate between $\mathrm{QoS}, \mathrm{F} \& \mathrm{~F}$ and SoC. Moreover positive and significant direct relationship founded between QoS and SoC
\end{abstract}

Keywords: Quality of Services (QoS), Family and Friends (F\&F), Satisfaction of Customer (SoC), Consumer Buying Decision (CBD).

DOI: $10.7176 / \mathrm{EJBM} / 11-12-18$

Publication date: April $30^{\text {th }} 2019$

\section{Introduction}

Telecommunication industry is playing one of the key role in GDP contribution of country almost with $60 \%$. As per Pakistan telecommunication authority (PTA), total subscribers in Pakistan are 152 million, 3G/4G subscriber are 60 million (Pakistan Telecommunication Authority, 2018). Aslama, Arifb, Farhatc, and Khursheedd (2018), conclude that QoS have dominant impact on SoC. Danish, Humayon, Iqbal, Raza, and Shahid (2018) provide advice companies, market is mature enough, instead of grabbing fresh customer it's time to save potential customers. In addition likings of customers are fluctuating quickly, which results in numerous encounters for companies (Chen, Hung, and and Huang, 2009). In support Huang (2011) beliefs that improvement in technology, enable service improvement conceivable with quick technological advancements. An advancement in technology benefited all of the companies, made our lives easy to handle issues, and further economic progress.

According to Shoemaker and Lewis (1999) appealing to old customers is less costly as compare to having new. In addition Siber (1997) beliefs cost of having new customer is greater than cost of appealing old one. Furthermore saving of potential customers is vital for success of companies (Hsu, Killion, and Gross and Huang, 2008). As per Som, Shirazi, Marzuki, and Jusoh (2011), beliefs "previous studies show 2\% increase in customer retention has the same effects on profits in terms of cost cutting by 10\%". Meanwhile Kim, Park, and Jeong (2004) conducted an empirical study and found that adjusting churn of customers is of major problems to telecom companies throughout the world, this problem will become bigger when market become hit the maturity level. As for as Fornell and Wernerfelt (1987), when market becomes mature, despite of attracting and grabbing new customer, better strategy is to be defensive (reduce the level of customer leaving and switching to other brands.

Reichheld, Teal, and and Smith (1996) suggestions if there is 5\% retaining of customers on average net present value (NPV) of customer will boost up with $35 \%$ among software firms and with $95 \%$ in advertising companies. Hence keeping in view the problem of saturated market wise decision should be to retain customers instead of focusing new one, and to explore the reasons behind brand switching. Number of scholars investigated the relationship between price, QoS and SoC. (Khan and Afsheen, 2012; Hanif, Hafeez, and Riaz, 2010; Loke, Taiwo, Salim, and Downe, 2011). In addition few of them examined the relationship of QoS, F\&F and CBD, (Ahmad and Ahmed, 2014; Lupo and Delbari, 2017; Agyeman, 2013; Ramya and Mohamed Ali, 2016).

Generally in telecommunication sector of Pakistan, customer are not needed to pay charges to switch service providers, in turn they are welcomed with multiple packages like three months free internet, SMS, minutes and other incentives, just decision, and courage is required (Jazz, 2019). Moreover one of biggest news comes up when Warid merged with Mobilink and claimed to serve approximately over 50 million customers (The Express Tribune, 2016). In order to gab new customers network providing companies are moving to doorsteps to sale their connection and increase their subscribers, along with it government also get assistance of telecom companies to provide jobs to female in context of Pakistan, this act was done by Benazir Income Support Program in 
collaboration with Telenor (BISP, 2018. This study investigate the how does QoS impact customer satisfaction? How does power of F\&F influence CBD against network services? And how consumer buying decision mediates the relationship of quality of service and satisfaction of customer? The one of the objective of the study to investigate the effects of QoS and F\&F on CBD. Another one to scrutinize the mediating role of CBD.

\section{Overview of Telecom Industry}

In year 1990s Paktel and Insta phone enter their foot as a Pioneer in Pakistan telecommunication industry. After 2000 s, there was increase in a competition every one try to have as much customer as possible. Currently Mobilink is consider market leader in telecom industry of Pakistan followed by Telenor, Zong, Ufone and warid. Moreover one of biggest news comes up when Warid merged with Mobilink and claimed to serve approximately over 50 million customers (The Express Tribune, 2016). As per Pakistan Telecommunication Authority (2018) Mobilink and Warid serve to 56.1 million customers, Telenor serve 43.1 million customers, Zong serve 31.7 million and finally Ufone have just 21.1 million customers.

The increasing rivalry within network providers are due to saturated market. Now companies are fighting more on retention and satisfaction of their customers because of which they are offering cheaply packages and free services etc. Now a days customers are in myth of having which operator with them as because they are having multiple benefits from each provider.

\section{Review of Literature}

Telecom sector contribute 60\% in GDP of Pakistan (Pakistan Telecommunication Authority, 2018). As per Danish, Humayon, Iqbal, Raza, and Shahid (2018) QoS have opulence impact of SoC. In addition Gautam and Chandhok (2011) discussed that leaving rate is greater in telecom industry as compare to other that is because of hyper competition. In addition Nelson (1970) argued that service quality has wealthy impact on consumer goods and scholars were enthusiastic towards consumer purchase decision in numerous industries. Kausar, Qureshi, Shehzad, and Hasan (2012) beliefs that potential customers are jumping to other network due to multiple reasons including QoS as well as additional services provided. According to Chaarlas, Rajkumar, Kogila, and Noorunnisha (2012) shifting of brands incur due to all elements of services (tangibility, empathy, assurance, reliability) as well as QoS, promotions, and price. As per Kausar, Qureshi, Shehzad, and Hasan (2012) findings quality of services leads to re-purchase buying behavior, and good word of mouth.

According to Makwana, Sharman, and Arora (2014) service quality is measured by communication, an innovation and addition in services. Furaiji, Łatuszyńska, and Wawrzyniak (2012) findings there was positive impact of marketing mix, social, personal, cultural and psychological on CBD. Furthermore Negi (2009) investigated the impact of service quality in telecom sector in Ethiopia and revealed that it has positive impact on consumers. In addition Aydin and Ozer (2005) also explored the relationship among perceived QoS along with the image of firm, perceived shifting cost, loyalty of customer and trust. Santish, Kumar, Naveen, and Jeevantham (2011) found that there is positive relationship between QoS and CBD. They found 47\% of potential customers shift to other service provider because of QoS. In addition Ashaduzzaman, Sohel Ahmed, and Khan (2011) did research on telecom sector of Bangladesh stated that there are total three success factors including price, QoS and brand image.

According to Dadzie and Mensah (2011) study conducted in Ghana, results revealed that price, promotion, availability and quality are the factors on basis of which consumer make purchase decision. In addition Jung and $\mathrm{Kau}$ (2004) beliefs that there is positive relationship between QoS along with other factors which impact consumer purchase behavior. Rajpurohit and Vasita (2011) conducted research in Malaysia and find out that role of F\&F in purchase decision of having network services, he reveals that factors which motivate consumers include quality of network coverage, call rate, and additional services offered, family and friends along with the advertisement. As per Kaapand (2012) investigated telecom sector in Namibia, most of the consumer's choice depends on QoS, call as well as SMS rates, reliability of network, discounts and promotions. According to Afzal, Shaikh, SM, Ghumro, and Khuhro (2013) results consumers give preferences to quality of network, services, voice clarity, and coverage. While Islam and Rima (2013) beliefs that in telecom sector of Pakistan, cellular service providers who use promotions gained greater market share.

\subsection{Hypothesis Constructs}

\subsubsection{Quality of Service and Satisfaction of customers}

Afthanorhan, Awang, Rashid, Foziah, and Ghazali (2018) found in their study that QoS has vital impact on SoC. Furthermore Nekmahmud and Rahman (2018) also find out the confident affiliation among the service qualities and customer satisfaction. In addition Gong and Yi (2018) also explored the encouraging association among the quality of services including all of its sub variable and satisfaction of customers. Furthermore Verma and Singh (2017) stated the positive impact of marketing mix (containing 7p's) on satisfaction of customers. As per Rendón, Vásquez, Arias, and Arias (2017) research findings there is positive relationship of services offered by telecommunication sector on satisfaction of customers. Furthermore, Mannan, Mohiuddin, Chowdhury, and Sarker 
(2017) also find that there was opulence relationship between factors of services and satisfaction of customers. As per Shafei and Tabaa (2016) investigation dominant the degree of quality of services dominant will be satisfaction of customers.

According to Arslan, Iftikhar, and Zaman (2015) investigation the association among satisfaction of customer quality of services is positive. As per Thaichona and Quachb (2015) findings quality of services dominantly influence the satisfaction of customers. In addition Ansar and Lodhi (2015) beliefs satisfaction of customers are not because of service qualities but it happens because of technology improvements. As per Makwana, Sharman, and Arora (2014) findings quality of services can be find by assurance, origination and value added services. While Khan and Afsheen (2012) believes that services of customers including quality of signal, fee, as well as advertising also have larger impact on satisfaction of customers.

According to Shah, Mudassir Husnain, and Zubairshah (2018) findings states that QoS including other variables also influence SoC towards buying behavior to have another services. Furthermore Aslam and Frooghi, (2018) beliefs that disappointment of one cellular network service enable us towards buying decision to get avail new services. As per Kurtkoti (2016) buying behavior of consumer is impacted by numerous elements containing (services offered, technology, price and delivery). In support Ahmad and Ahmed (2014) results reveals that quality of services has positive impact on consumer buying behavior. In addition Schiffman and Kanuk (2009) consider QoS as vital cause to impact CBD.

$H_{1}=$ QoS has positive and significant influence on $S o C$.

2.1.2 Family \& Friends and Consumer Buying Behavior.

As per Jain and Singh (2019) results out of five hundred respondent's one hundred twenty respondents declared that their choice to buy new smart phones are impacted by F\&F. Furthermore Shah, Mudassir Husnain, and Zubairshah (2018) states that F\&F having other factors involving QoS have positive impact of SoC which leads to CBD. In addition Johnson (2014) investigated that $81 \%$ of defendants revealed that F\&F straight forwardly impact their buying decisions. Furthermore psychology teacher Jenna Breuer, revealed that families have greater impact as because family is the $1^{\text {st }}$ social representatives that children are visible to (Guo, 2014). In addition Rani (2014) states that F\&F have more power of impact to purchase decision. In support Agyeman (2013) also investigated the dominant relationship between $\mathrm{F} \& \mathrm{~F}$, relative, coworkers on purchase decision.

\section{$\mathrm{H}_{2}=\mathrm{F} \& \mathrm{~F}$ has positive and significant influence on $\mathrm{CBD}$.}

\subsubsection{Consumer buying behavior and satisfaction of customers}

(Qalati, at el, (2019), investigated the mediating role of CBD between price and SoC. Furthermoere scholars founded the positive and significant results of mediation. In addition According to Susanto (2013), findings CBD has significant relationship with SOC. Furthermore he recommended to use purchase decision in other industries. This shows a positive impact of customer buying decisions on customer satisfaction, however consumer purchase decision has not been investigated so far as a mediator in relationship of service quality, family friends and customer satisfaction. This study will uniquely add up in the literature of study of customer purchase decision as a mediator. To check this relationship following hypothesis has been constructed:

$H_{3}=$ the relationship between $Q o S$ and $S o C$ is mediated by $C B D$.

\section{Methodology of Research}

In order to keep in mind term biasness, closed ended questionnaire five point Likert sale is used $(1=$ Strongly Agree, $2=$ Agree, $3=$ Neutral, $4=$ Disagree and $5=$ Strongly Disagree).

For Quality of Service variable total 19 points scale was used to measure this variable, the scale used by Loke, Taiwo, Salim, and Downe (2011) the reliability of the scale was measured 0.950 . For family and friends variable total 3 points scale was used to measure this variable, in order to find out the just effect of family and friends 2 items have been added while 1 items have been taken from the scale was used by Paulrajan and Harish (2011) and Ahmad and Ahmed (2014) the reliability of scale was measured 0.906. For consumer buying decision variable total 6 points scale was used to measure this variable, the scale was used by Ahmad and Ahmed (2014) the reliability of scale was measured $\mathbf{0 . 8 2 1}$. For measuring satisfaction of customer variable total 4 points scale was used to measure the variable, this scale was used by Oladepo and Abimbola (2014) the reliability of this scale was measured 0.944 . 


\subsection{Construct Reliability and Validity}

\begin{tabular}{|l|l|l|l|}
\hline Quality of Services & Total Items & Cronbach Alpha & Reliability \\
Family and Friends & 19 & 0.944 & 0.950 \\
Consumer Buying Decision & 3 & 0.856 & 0.906 \\
Satisfaction of Customer & 4 & 0.711 & 0.821 \\
\hline
\end{tabular}

The above table depicts that as per standards set by Nunnally (1978) the Cronbach alpha coefficient must be greater than 0.7 and Hinton, Brownlow, McMurray, and Cozens (2004) suggested four levels of reliability $01-$ excellent reliability falls within range of 0.9 and $>$, while high reliability in 0.7 to 0.9 , moderate from 0.5 to 0.7 and low but also acceptable $<0.5$. Albeit the variables used in this study falls in region of excellent reliability except consumer buying decision which also falls in high category.

In order to collect data closed ended questionnaire was created through google form for an ease of respondents, and link has been shared via popular social sites Facebook, WhatsApp, WeChat, Snap Chat, as well as through email. And keeping in view the literacy rate of Pakistan field survey also conducted to satisfy the study. Major area were covered through field include 04 provinces, of Pakistan, Baluchistan, Panjab, KPK and Sindh. While among them major cities include Karachi, Lahore, Quetta, Islamabad, Sukkur, Hyderabad, and Larkana. Throughout the Pakistan online as well as offline in total $\mathbf{5 6 7}$ responses received. Data was processed by using Smart PLS 3.2.7.

\subsection{Conceptual Framework}

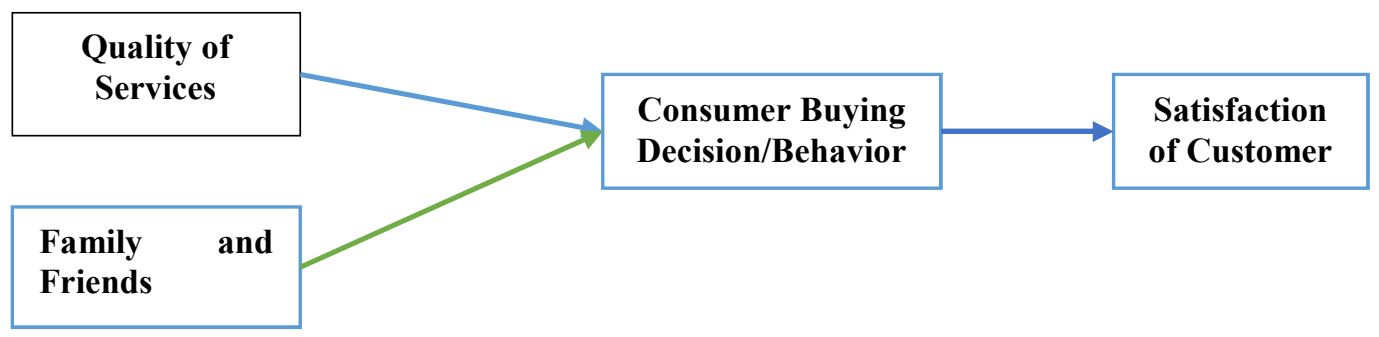

Source: Researcher's Conceptual Model

\subsection{Result Analysis:}

\subsubsection{Demographic information of Respondents}

In Gender out of 567 respondents 392 (69\%) were males and 175 (31\%) were females.

In Age out of 567 respondents 42 (7.5\%) respondents lies in range of 10 - 20, while $406(71.5 \%)$ respondents lies in range of $21-30$, furthermore $84(15 \%)$ belongs to age of $31-40$, in last $35(6 \%)$ lies in range of, $41-50$.

In Occupation: this area of demographic further divided into 04 categories 01 Government Employee 58 (10\%) respondents have job in government sectors, 02 Private Sector 154 (27\%) respondents have private jobs, 03 Students 294 (52\%) respondents fall into this category, 04 Entrepreneurs involve those respondents who answered with owner, businessman these are $61(11 \%)$ in total.

In Total family members out of 567 respondents 203 (36\%) falls into category of 0 - 5, while $280(49.5 \%)$ into 6 - 10, further $66(11.5 \%)$ into $11-15$, in last $18(3 \%)$ falls into category of $16-20$.

In Education category divided into 5 levels out of 567 respondents 14 (2.5\%) falls into basic - matric level, $42(7.5 \%)$ lies into intermediate, $218(38.5 \%)$ have did or still doing bachelor, while $266(47 \%)$ are having master degree, while 27 (4.5\%) have PhD level of education.

In Response to possession of Mobile Phone? Out of 567 respondents 98 (17\%) possess Apple iPhone, 231 (40.5\%) have Samsung, 98 (17\%) have Huawei, and 84 (15\%) have Oppo, Nokia hold by 28 (5\%), Xiaomi have 14 (2.5\%) and Hair also have 14 (2.5\%).

In response to Q1 - Which is your current cellular service provider? (Tick more option if you have more than one)? Out of 567 respondents 154 (27\%) respondent have Mobilink, $112(20 \%)$ have Ufone, 63 (11\%) have Zong, 42 (7.5\%) have Telenor, 14 (2.5\%) have Warid network, while 182 (32\%) respondents have more than one network.

In response to Q2 - Which service provider is best in your perspective? Out of 567 respondents 224 (39.5\%) respondents selected Mobilink to become best service provider, 175 (31\%) selected Zong, 112 (20\%) given credit 
to Ufone, $42(7.5 \%)$ are with Telenor, while 14 (2.5\%) are with Warid.

In response to Q3 - Which will you prefer most for mode of communication with family and friends? 245 (43.5\%) respondents replied that they are using SMS/Call for their communication. 210 (37\%) are using WhatsApp, $14(2.5 \%)$ replied with Facebook Messenger, while rest of 98 (17\%) selected other option (it include different social application like Snap Chat, Viber, and Imo).

Table - 1: Measurement Model

\begin{tabular}{|c|c|c|c|c|c|}
\hline & Items & Loading $^{\mathbf{a}}$ & $\mathbf{A V E}^{\mathbf{b}}$ & $\mathbf{C R}^{\mathbf{c}}$ & $\mathbf{C A}^{\mathrm{d}}$ \\
\hline Quality & QoS1 & 0.645 & 0.503 & 0.95 & 0.944 \\
\hline of & QoS2 & 0.812 & & & \\
\hline \multirow[t]{17}{*}{ Services } & QoS3 & 0.567 & & & \\
\hline & QoS4 & 0.716 & & & \\
\hline & QoS5 & 0.774 & & & \\
\hline & QoS6 & 0.744 & & & \\
\hline & QoS7 & 0.774 & & & \\
\hline & QoS8 & 0.637 & & & \\
\hline & QoS9 & 0.764 & & & \\
\hline & QoS10 & 0.73 & & & \\
\hline & QoS11 & 0.633 & & & \\
\hline & QoS12 & 0.718 & & & \\
\hline & QoS13 & 0.74 & & & \\
\hline & QoS14 & 0.636 & & & \\
\hline & QoS15 & 0.771 & & & \\
\hline & QoS16 & 0.556 & & & \\
\hline & QoS17 & 0.536 & & & \\
\hline & QoS18 & 0.772 & & & \\
\hline & QoS19 & 0.852 & & & \\
\hline Consumer & CBD1 & 0.758 & 0.537 & 0.821 & 0.711 \\
\hline Buying & CBD4 & 0.583 & & & \\
\hline \multirow[t]{2}{*}{ Decision } & CBD5 & 0.787 & & & \\
\hline & CBD6 & 0.784 & & & \\
\hline Family and & QFF1 & 0.958 & 0.767 & 0.906 & 0.856 \\
\hline \multirow[t]{2}{*}{ Friends } & QFF2 & 0.938 & & & \\
\hline & QFF3 & 0.709 & & & \\
\hline Satisfaction & SoC1 & 0.88 & 0.809 & 0.944 & 0.921 \\
\hline \multirow[t]{3}{*}{ of Customers } & SoC2 & 0.913 & & & \\
\hline & SoC3 & 0.924 & & & \\
\hline & SoC4 & 0.879 & & & \\
\hline
\end{tabular}

Note:

a) All items loadings $>0.5$ indicates indicator reliability (Chin W, 2010)

b) All average variance extracted (AVE) $>0.5$ indicates convergent reliability (Bagozzi and Yi, 1988)

c) All composite reliability (CR) $>0.7$ indicates internal consistency (Gefen, Straub, and Boudreau, 2000)

d) All Cronbach's alpha $>0.7$ indicates indicator reliability (Nunnally, 1978)

Table - 2: Discriminant Validity (Fornell-Larker Criterion)

\begin{tabular}{|l|l|l|l|l|}
\hline & CBD & F\&F & QoS & SoC \\
\hline$C B D$ & $* \mathbf{0 . 7 3 3}$ & & & \\
\hline$F \& F$ & 0.431 & $* \mathbf{0 . 8 7 6}$ & & \\
\hline$Q o S$ & 0.574 & 0.373 & $* \mathbf{0 . 7 0 9}$ & \\
\hline$S o C$ & 0.583 & 0.411 & 0.689 & $* \mathbf{0 . 8 9 9}$ \\
\hline
\end{tabular}

* The diagonals are the square root of AVE of the latent variables and indicates highest in column and row. 


\begin{tabular}{|l|l|l|l|l|}
\multicolumn{7}{|c|}{ Table-3: Heterotrait-Monotrait Ratio (HTMT) } \\
\hline & CBD & F\&F & QoS & SoC \\
\hline$C B D$ & & & & \\
\hline$F \& F$ & 0.507 & & & \\
\hline$Q o S$ & 0.685 & 0.393 & & \\
\hline$S o C$ & 0.704 & 0.429 & 0.816 & \\
\hline
\end{tabular}

According to Henseler, Ringle, ad Sarstedt (2015) lack of discriminant validity must be examined by HTMT ratio. "It is the geometric mean of the heterotrait-heteromethod correlations (the correlations of indicators across constructs measuring different phenomena) divided by the average of the monotrait-heteromethod correlations (the correlations of indicators within the same construct)". It should be $<1$. According to Henseler, Ringle, and Sarstedt (2015) it should be $<0.9$, (Kline, 2011) beliefs that it should be $<0.85$.

Table - 4: Hypothesis Construct

Note: $* * p<0.01$ (one tailed test)

\begin{tabular}{|l|l|l|l|l|l|l|}
\hline Hypothesis & & Beta & SE & t-value & p-value & Decision \\
\hline$H_{1}$ & $Q o S->S o C$ & 0.644 & 0.036 & 17.717 & $* * 0.000$ & Supported \\
\hline$H_{2}$ & $F \& F->S o C$ & 0.097 & 0.031 & 3.138 & $* * 0.002$ & Supported \\
\hline$H_{3}$ & $Q o S->C B D->S o C$ & 0.082 & 0.024 & 3.364 & $* * 0.001$ & Supported \\
\hline
\end{tabular}

$\mathbf{H}_{1}$ constructed that QoS has positive and significant influence on SoC. Results founded with positive beta coefficient 0.644 , standard error 0.036 , t-value $17.717>2$ and $\mathrm{p}$-value $0.000<0.01$. The hypothesis supported by Afthanorhan, Awang, Rashid, Foziah, and Ghazali (2018), Gong and Yi (2018) and Verma and Singh (2017).

$\mathbf{H}_{2}$ established that F\&F has positive and significant influence on CBD. The result founded with positive beta coefficient 0.097 , standard error 0.031 , t-value $3.138>2$, and p-value $0.002<0.01$. Hence hypothesis founded significant and supported by (Jain and Singh, 2019; Shah, Mudassir Husnain, and Zubairshah, 2018; and Johnson, 2014).

$\mathbf{H}_{3}$ was constructed that the relationship between QoS and SoC mediated by CBD. The results founded with positive coefficient 0.082 , standard error 0.024 , t-value $3.364>2$ and p-value $0.001<0.01$. Hence the decision against hypothesis was supported. Furthermore the hypothesis constructed supported by studies of (Qalati, at el, 2019, and Susanto, 2013).

\subsubsection{Correlation Analysis:}

Table - 5: Latent Variable Correlation

\begin{tabular}{|l|l|l|l|l|}
\hline & CBD & F\&F & QoS & SoC \\
\hline$C B D$ & $\mathbf{1}$ & 0.431 & 0.574 & 0.583 \\
\hline$F \& F$ & 0.431 & $\mathbf{1}$ & 0.373 & 0.411 \\
\hline$Q o S$ & 0.574 & 0.373 & $\mathbf{1}$ & 0.778 \\
\hline$S o C$ & 0.583 & 0.411 & 0.778 & $\mathbf{1}$ \\
\hline
\end{tabular}

The above table shows the relationship between variables used in the study strongest relationship was founded between $0.778 \mathrm{QoS}$ and SoC, followed by $0.583 \mathrm{SoC}$ and CBD. While the weaker relationship founded between $0.373 \mathrm{~F} \& \mathrm{~F}$ and SoC, followed by $0.411 \mathrm{~F} \& \mathrm{~F}$ and SoC. All value were find out significant with $\mathrm{p}$ value 0.000 which is $<0.01$.

Table - 6: Specific Indirect Effects

\begin{tabular}{|c|c|c|c|c|c|}
\hline & Beta & SE & t-value & p-value & Decision \\
\hline$F \& F->C B D->S o C$ & 0.043 & 0.012 & 3.477 & 0.001 & Supported \\
\hline$Q O S->C B D->S O C$ & 0.082 & 0.024 & 3.364 & 0.001 & Supported \\
\hline
\end{tabular}

The above table states that the relationship between F\&F and SoC mediated by CBD founded significant with beta coefficient 0.043 , standard error 0.012 , t-value $3.477>2$, and p-value $0.001<0.01$. Likewise the relationship between $\mathrm{QoS}$ and SoC positively and significantly mediated by CBD with positive beta coefficient 0.082 , standard error 0.024 , t-value $3.364>2$, and p-value $0.001<0.01$. Hence the decision against mediation supported by using p-value and t-value.

Table $-7: \mathrm{R}^{2}$ Coefficient of Determination
\begin{tabular}{|l|l|l|l|l|l|}
\hline & Beta & SE & t-value & p-value & Decision \\
\hline$C B D$ & $* 0.384$ & 0.03 & 12.679 & 0.000 & Supported \\
\hline$S o C$ & $* 0.641$ & 0.022 & 29.552 & 0.000 & Supported \\
\hline
\end{tabular}

Note: *In PLS-SEM R ${ }^{2}$ with values of 0.67 considered substantial, 0.33 considered moderate, and 0.19 as weak (Chin, 1998).

The table -7 shows the level of variation in dependent variable incur because of independent variables. $\mathrm{R}^{2}$ is the coefficient of determination, it tells about the variation. Or how much in \% dependent variable is defined by 
independent variables. Hence $0.384(38.4 \%)$ variation in $\mathrm{CBD}$ is defined by QoS and F\&F which was also significant with p-value 0.000 which was $<0.01$. Furthermore $0.641(64.1 \%)$ variation in SOC is defined by QoS and $\mathrm{F} \& \mathrm{~F}$ which was also significant with p-value 0.000 which was $<0.01$.

\subsubsection{Regression Analysis through (SEM)}

Structural Equation Model

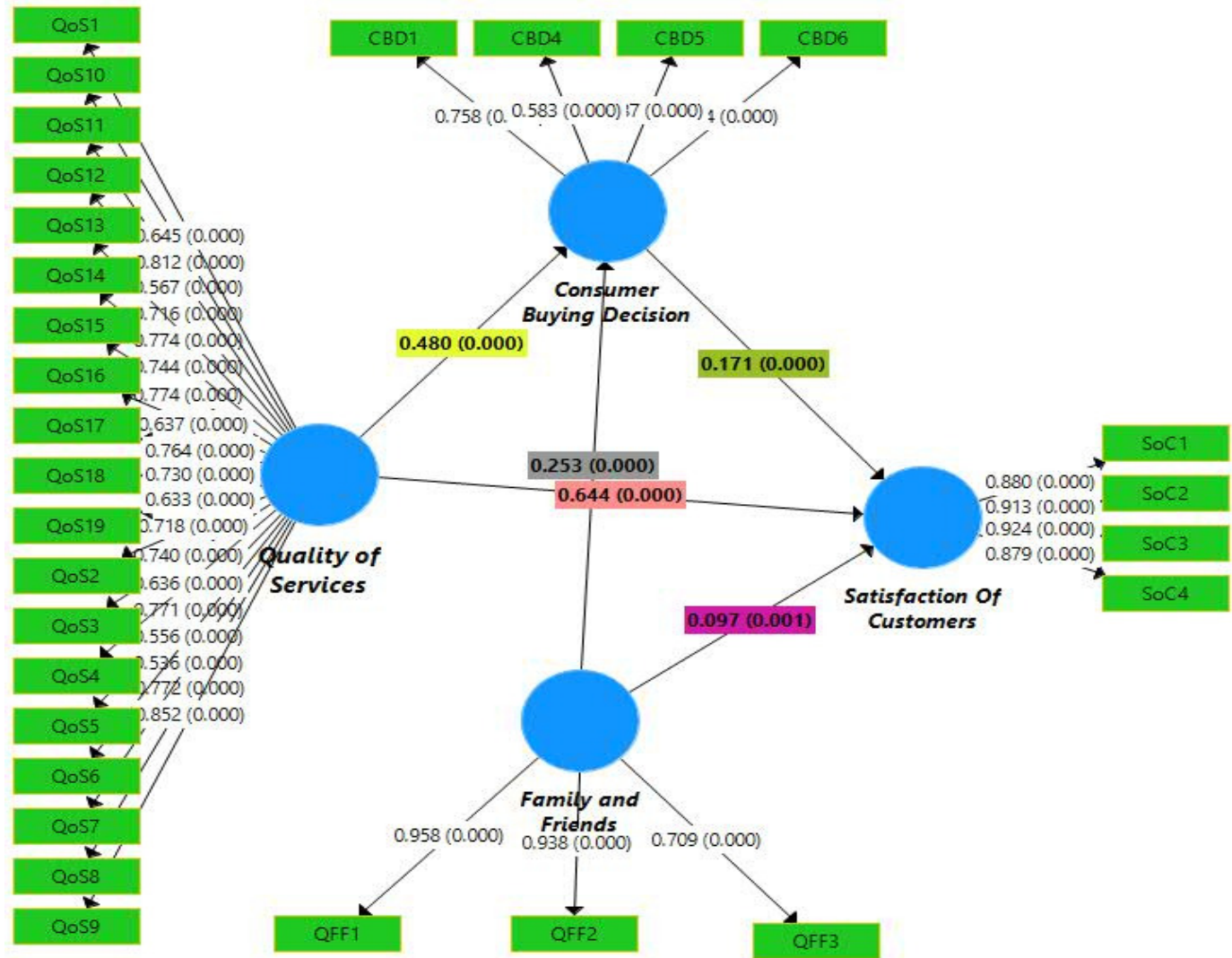

Figure - 1: The bootstrapping technique used for above figure, it shows the path coefficients along with their significance, all paths have positive coefficients and among them QoS - SoC, QoS - CBD and F\&F - CBD as well as CBD - SoC were significance by having significance level 0.000 , while F\&F - SoC have 0.001 all paths were significant because their $\mathrm{p}$ value was $<0.01$.

\section{Conclusion and Recommendation}

This study supported the positive and significant influence of QoS, F\&F on CBD and SoC which is consistant with the studies of Ansar and Lodhi (2015), Arslan, Iftikhar, and Zaman (2015), Afthanorhan, Awang, Rashid, Foziah, and Ghazali (2018) and Shah, Mudassir Husnain, and Zubairshah (2018). CBD acted as mediator between QoS, F\&F and SoC but the level of relationship among them was not that much strong $4.3 \%$ among QoS and SoC and approximately 8.2\% among F\&F and SoC (Qalati, at el, 2019, and Susanto, 2013). Furthermore potential customers are more prone towards QoS in context of Pakistan as coefficient 0.778 witnessed that thing. As per findings, $\mathrm{H}_{1}$ and $\mathrm{H}_{2}$ there is positive and significant influence of QoS, F\&F on SoC results founded significant as exhibited in table -4 . The $\mathrm{H}_{3}$ - the relationship between SoC and SoC positively and significantly mediated by the CBD (Qalati, at el, 2019, and Susanto, 2013), used CBD as mediator in study of hospitality and telecom services, hence this research motive also to be novel in the telecom industry of Pakistan.

The most youngster were using cell phone as per findings $71.5 \%$ falls into category of $21-30$. Furthermore usage of mobile phone is greater in male $69 \%$ value declared that. Moreover another findings include the use of social applications in increasing in Pakistan as per results 37\% respondents were using WhatsApp. Moreover 40\% respondent have Samsung mobiles, followed another popular brand in Pakistan is Apple iPhone, Oppo. Furthermore $58 \%$ respondents have master level of education and $38.5 \%$ have bachelor level of education. $52 \%$ of occupation as students exhibited that students were using mobile phones that could be the reasons of having more than multiple network services as $32 \%$ of respondents selected. As we know that Mobilink is considered market leader, in telecom industry of Pakistan, 27\% respondent have Mobilink network sim followed by Ufone, Zong and Warid. Furthermore 39.5\% respondents have given vote to Mobilink to become best service provider followed by Zong 31\%.

Meanwhile this study will declared that QoS are consider major factor for satisfaction as well as buying 
decision, hence cellular companies should focus on this quality of services either in house or technical. Furthermore youngsters are brand conscious they will prefer branded cell phones, having feature of more than one Sim and imbibed social applications like WhatsApp. Along with quality of services companies should focus on quality of signals, and coverage as well as internet packages, because results noted have insights of using social application is increasing in future.

\section{Limitation and Future Directions}

Apart from the QoS and F\&F other variable could be used with mediator to know further impact of CBD in other or same industry. Cell phone companies should endorse youngster for increasing their growth in Pakistan. Same study can be used in other countries. Scope of internet and usage of mobile is increasing, which predicted that scope of online buying is going to be increasing in future. Business model should be developed having online buying and selling services

\section{References}

Abdul, F., Salman, A., \& Olota, O. (2014). Impact of Customer Satisfaction on Mobile Telecommunication Service Provider. Jorind, 12(2), 139-152.

Afthanorhan, A., Awang, Z., Rashid, N., Foziah, H., \& Ghazali, P. (2018, September ). Assessing the effects of service quality on customer satisfaction. Management Science Letters, 9(2019), 13-24.

Afzal, S. C., Shaikh, A., SM, B., Ghumro, B., \& Khuhro, A. (2013). Factors behind Brand Switching in Cellular Networks. International Journal of Asian Social Science, 3(2), 299-307.

Agyeman, G. (2013). Culture as a catalyst influencing buying behavior of Mobile Phone in Koforidua. European journal of Business and Management, 5(7), 88-95.

Agyeman, G. (2013). Culture as a catalyst influencing buying behavior of Mobile Phone inKoforidua. European journal of Business and Management, 5(7), 88-95.

Ahmad, Z., \& Ahmed, J. (2014). Consumer Purchase Behavior in Cellular Service Sector of Pakistan. Journal of Business and Management, 16(5), 62-75.

Ansar, A., \& Lodhi, S. (2015). The impact of service quality on customer satisfaction in telecom sector of Pakistan. An empirical study of Pakistan. International Journal of Scientific \& Engineering Research, 6(10), 16391645 .

Arslan, M., Iftikhar, M., \& Zaman, R. (2015). Effect Of Service Quality Dimensions on Customer Satisfaction A Comparative Analysis of Pakistan Telecom Sector. British Journal of Marketing Studies, 43-62.

Ashaduzzaman, M., Sohel Ahmed, S. M., \& Khan, M. M. (2011). Consumer Choice Behavior Towards Mobile Phone. Journal of Arts, Science \& Commerce, 30-39.

Aslam, W., \& Frooghi, R. (2018). Switching Behaviour of Young Adults in Cellular Service Industry: An Empirical Study of Pakistan. Global Business Review, 19(3), 1-15.

Aslama, W., Arifb, I., Farhatc, K., \& Khursheedd, M. (2018). The Role of Customer Trust,Service Quality and Value Dimensions in Determining Satisfaction and Loyalty: An Empirical Study of Mobile Telecommunication Industry in Pakistan. Market-Tržište, 30(2), 177-194.

Aydin, S., \& Ozer, G. (2005). . (2005). The analysis of antecedents of customer loyalty in the Turkish mobile telecommunication market. European Journal of Marketing, 910-925.

Bagozzi, R. P., \& Yi, Y. (1988). On the evaluation of structural equation models. Journal of the Academy of Marketing Science, 16(1), 74-94.

Baohong, S., Scott, N., \& Kannan, S. (2003). Measuring the Impact of Promotions on Brand Switching When Consuemr are Forward Looking. Journal of Marketing Research, 40(4), 389-405.

BISP. (2018, October 10). BISP Join Hands with Telenor Pakistan To Employee 20,000 Female Beneficiaries October 10, 2018. Retrieved from bisp.gov.pk: http://bisp.gov.pk/bisp-join-hands-with-telenor-pakistan-toemployee-20000-female-beneficiaries-october-10-2018/

Chaarlas, L., Rajkumar, R., Kogila, N., \& Noorunnisha, A. (2012). Service Related Issue Faced by Clients - The Major Cause Behind Brand Switching in Cellular Phone Service Industry. Arabian Journal of Business and Management Review, 33-46.

Chen, J., Hung, T., \& and Huang, Y. (2009). Service delivery innovation antecedents and impact on firm performance. Journal of Service Research, 12(1), 36-55.

Chin, W. (1998). The partial least squares approach to structural equation modeling. Modern Methods for Business Research, 292(2), 295-336.

Chin, W. (1998). The partial least squares approach to structural equation modeling. Modern Methods for Business Research, 292(2), 295-336.

Dadzie, A., \& Mensah, F. B. (2011). Brand Preference for Mobile Phone Operator Services in the Cape Coast Metropoli . International Journal of Business and Management, 190-205.

Danish, R., Humayon, A., Iqbal, H., Raza, S., \& Shahid, J. (2018). The Impact of Service Quality and Service 
Value on Customer Satisfaction through Customer bonding: Evidence from telecommunication Sector. European Online Journal of Natural and Social Sciences, 7(1), 40-47.

Darmawan, M. (2018). The Effect Of Price, Product Quality, Promotion, Social Factor, Brand Image on Purchase Decision Process of Loop Product on Youth Segment (Case Study of Pt Telekomunikasi Selular). International Seminar \& Conference on Learning Organization (pp. 294-309). ISCLO 6th, 2018.

Fornell, C., \& Wernerfelt, B. (1987). Defensive marketing strategy by customer complaint management, A theoretical analysis. Journal of Marketing Research, 24(4), 337-346.

Furaiji, F., Łatuszyńska, M., \& Wawrzyniak, A. (2012). An Empirical Study of the Factors influencing Consumer Behaviour in the Electric Appliances Market. Basra University, 6(3), 76-86.

Gautam, P., \& Chandhok, A. (2011). Switching Behaviour of Subscribers in India Telecom Sector. International Journal of Research in Finance and Marketing, 1(3), 183-191.

Gefen, D., Straub, D., \& Boudreau, M.-C. (2000). Structural Equation Modeling and Regression Guidelines for Research Practice. Communications of the Association for Information Systems, 4(7), 1-77.

Gong, T., \& Yi, Y. (2018). The effect of service quality on customer satisfaction, loyalty, and happiness in five Asian countries. Wiley Psychol Mark, 1-16.

Guo, K. (2014, November 18). How do family, peers influence us? Retrieved from Statesman: https://www.statesmanshs.org/913/features/how-do-family-peers-influence-us/

Han, Heesup, \& Hyun, S. (2014). Customer retention in the medical tourism industry: Impact of quality satisfaction, trust, and price reasonableness. Tourism Management, 46.

Hanif, M., Hafeez, S., \& Riaz., A. (2010). Factors Affecting Customer Satisfaction. International Research Journal of Finance and Economics, 44-52.

Hawkins, D., Mothersbaugh, D., \& Mookerjee, A. (2010). Consumer Behavior Building Marketing Strategy (11th ed.). McGraw-Hill/Irwin;.

Henseler, J., Ringle, C. M., \& Sarstedt, M. (2015). A new criterion for assessing discriminant validity in variancebased structural equation modeling. Journal of the Academy of Marketing Science, 43(1), 115-135.

Hinton, P. R., Brownlow, C., McMurray, I., \& Cozens, B. (2004). SPSS Explained. : . East Sussex, England: Routledge Inc.

Hsu, C. L., Killion, G. B., \& M Gross and Huang, S. (2008). Tourism Marketing: An Asia-Pacific Perspective. Australia: John Wiley \& Sons.

Huang, K. (2011). A comparative study to classify ICT developments by economies. Journal of Business Research, 64(11), 1174-1177.

Islam, M., \& Rima, A. (2013). Factors Affecting Customer Experience in Telecommunication Service and its Importance on Brand Equity A Study on Telecommunication Companies in Bangladesh. Journal of Contemporary Research in Business, 5(8), 254-262.

Jain, S., \& Singh, B. (2019). Consumer Behavior Toward Mobile Phone Handsets. International Conference on Innovative Computing and Communications, (pp. 61-69). Rajasthan, India .

Jazz. (2019, February 9). Switch to Jazz. Retrieved from www.jazz.com.pk: https://www.jazz.com.pk/explore/getstarted/switch-to-jazz-network/

Johnson, W. (20014, October 28). What's the Biggest Influencer in Consumer Purchase Decisions? Retrieved from Small Business Trends: https://smallbiztrends.com/2014/10/influence-consumer-purchasedecisions.html

Jung, K., \& Kau, A. K. (2004). Culturee s Influence on Consumer Behaviors Differences Among Ethnic Groups in a Multiracial Asian Country. Advances in Consumer Research, 31, 362-372.

Kaapand, L. N. (2012). An Evaluation of Factors Determining the Selection of Mobile Telecommunications Service Providers in the Northern Region of Namibia. 3rd International Conference on Business and Ecnomic Research (3rd ICBER 2012) Proceeding, (p. 23). Namibia.

Kausar, D., Qureshi, S., Shehzad, F. A., \& Hasan, H. (2012). Factors Influencing the Customere's Satisfaction and Switching Behavior in Cellular Services of Pakistan. Interdisciplinary Journal of Research in Business, 2(1), $15-25$.

Keller, K. L. (2008). Strategic Brand Management, Second Edition. New Delhi: Prentice Hall of India.

Khan, M. (2010). An Empirical Assessment of Service Quality of Cellular Mobile Telephone Operators in Pakistan. Asian Social Science, 164-177.

Khan, S. (2012). Contribution of Brand Awareness and Brand Characteristics towards Customer Loyalty A Study of Milk Industry of Peshawar Pakistan. Journal of Asian Business Strategy, 2(8), 170-176.

Khan, S., \& Afsheen, S. (2012). Determinants of Customer Satisfaction in Telecom Industry A Study of Telecom industry Peshawar KPK Pakistan. Journal of Basic and Applied, 2 (12), 12833-12840.

Kim, M., Park, M., \& and Jeong, D. (2004). The effects of customer satisfaction and switching barrier on customer loyalty in Korean mobile telecommunication services. Telecommunications Policy, 28(2), 145-159.

Kline, R. B. (2011). Principles and practice of structural equation modeling. New York: Guilford Press. . 
Kouser, R., Qureshi, S., Shahzad, F., \& H., a. H. (2012). Factors Influencing the Customer Satisfaction and Switching Behavior on Cellular Service of Pakistan. Interdisciplinary Journal of Research in Business, 2(1), $15-25$.

Kurtkoti, D. (2016). Factors Influencing Consumer Buying Decision Process For Different Products And Brands. Journal of Management \& Research, 6(1).

Loke, S.-P., Taiwo, A. A., Salim, H. M., \& Downe, A. G. (2011). Service Quality and Customer Satisfaction in a Telecommunication Service Provider. 2011 International Conference on Financial Management and Economics (pp. 24-29). Singapore: IACSIT Press.

Lupo, T., \& Delbari, A. S. (2017). A knowledge-based exploratory framework to study quality of Italian mobile telecommunication services. Telecommun System, 1-16.

Makwana, K., Sharman, N., \& Arora, S. (2014). Factors Influencing Consumer Brand Switching Behaviour in Telecommunication Industry: An Empirical Study. Prestige- E Journals of Management and Research, 1(1).

Mannan, M., Mohiuddin, M., Chowdhury, N., \& Sarker, P. (2017). Customer satisfaction, switching intentions, perceived switching costs, and perceived alternative attractiveness in Bangladesh mobile telecommunications market. South Asian Journal of Business Studies, 6(2).

Munnukka, J. (2008). Consumers' purchase intentions as a reflection of price perception. Journal of Marketing, $58(3), 3-20$.

Negi, R. (2009). Users' perceived service quality of mobile communications; experience from Ethiopia. International Journal of Quality and Reliability Management,, 699-711.

Nekmahmud, M., \& Rahman, S. (2018). Measuring the Competitiveness Factors in Telecommunication Markets. Management Science, 339-372.

Nelson, P. (1970). Information and Consumer Behavior. . Journal of Political Economy, 311-329.

Nunnally, J. C. (1978). Psychometric Theory.: New York: McGraw-Hill.

Nunnally, J. C. (1978). Psychometric Theory.: New York: McGraw-Hill.

Ojo, O. (2010). The relationship between service quality and customer satisfaction in the telecommunication industry: evidence from Nigeria. Broad Research in Accounting Negotiation, and Distribution,, 1(1), 88-100.

Oladepo, O., \& Abimbola, O. (2014). Telecommunication Service Delivery And Customer Satisfaction: A Study of Telecom Subscribers in Ogun State, Nigeria. International Journal of Business and Management Review, 2(6), 49-58.

Qalati, S., Yuan, L., Iqbal, S., Hussain, R., \& Ali, S. (2019). Impact of Price on Customer Satisfaction; mediating role of Consumer Buying Behaviour in Telecom Sector. International Journal of Research, 6(4), 150-165.

Pakistan Telecommunication Authority. (2018, December). Telecom Indicator. Retrieved from Pakistan Telecommunication Authority: https://pta.gov.pk/en/telecom-indicators

Pakola, J., Pietila, M., Svento, R., \& Karjaluoto, H. (2001). An investigation of consumer behavior in mobile phone markets in Finland. New Technologies and E-Marketing. Finland: 32nd EMAC Conference, Track.

Paulrajan, R., \& Harish, R. (2011). Service quality and customers preference of cellular mobile service providers. Paulrajan, R. and Harish, R., 6(1), 38-45.

Rajpurohit, P. R., \& Vasita, D. M. (2011). Consumer Preferences and Satisfaction towards various Mobile Phone Service Providers. Gurukul Business Review, 7, 1-11.

Rajput, D. A., Kalhoro, S. H., \& Wasif, R. (2012). Impact of Product Price and Quality on Consumer Buying Behavior: Evidence from Pakistan. Interdisciplinary Journal of Contemporary Research in Business, , 485496.

Ramya, N., \& Mohamed Ali, S. (2016). Factors affecting consumer buying behavior. International Journal of Applied Research 2016, 2(10), 76-80.

Rani, P. (2014). Factors influencing consumer behaviour. Int.J.Curr.Res.Aca.Rev, 2(9), 52-61.

Reichheld, F., Teal, T., \& and Smith, D. (1996). The Loyalty Effect. Boston, MA: Harvard Business School Press.

Rendón, C., Vásquez, A., Arias, M., \& Arias, A. (2017). Proposed Model for Measuring Customer Satisfaction with Telecommunications Services. Mediterranean Journal of Social Sciences, 8(2), 15-25.

Santish, M., Kumar, K. S., Naveen, K. J., \& Jeevantham, V. (2011). A Study of Consumer Switching Behavior in Cellular Service Prodider; A study with reference to Chennai. Far East Journal of Psychology and Business, 2(2), 71-81.

Schiffman, L., \& Kanuk, L. (2009). Consumer Behavior 10th Edition. Prentice Hall.

Shafei, I., \& Tabaa, H. (2016). Factors affecting customer loyalty for mobile telecommunication industry. EuroMed Journal of Business, 11(3), 1-12 to 1-2.

Shah, M., Mudassir Husnain, M., \& Zubairshah, A. (2018). Factors Affecting Brand Switching Behavior in Telecommunication Industry of Pakistan: A Qualitative Investigation. American Journal of Industrial and Business Management, 2018(8), 359-372.

Shoemaker, S., \& and Lewis, R. (1999). Customer loyalty: The future of hospitality marketing. International Journal of Hospitality Management, 18(4), 345-370. 
Siber, R. (1997). Combating the churn phenomenon. Telecommunications, 31(10), 77-81.

Som, A., Shirazi, S., Marzuki, A., \& and Jusoh, J. (2011). A critical analysis of tourist satisfaction and destination loyalty. Journal of Global Management,, 2(1), 178-183.

Susanto, A. (2013, December 4). The Influence of Customer Purchase Decision on Customer Satisfaction and it's Impact to Customer Loyalty . Jurnal EMBA, 1(4), 1659-1666.

Thaichona, P., \& Quachb, T. (2015). The relationship between service quality, satisfaction, trust, value, commitment and loyalty of Internet service providers' customers. Journal of Global Scholars of Marketing Science, 25(4), 295-313.

The Express Tribune. (2016, July 12). Merger of Warid-Mobilink now complete. Retrieved from Tribune: https://tribune.com.pk/story/1134411/merger-warid-mobilink-now-complete/

Verma, Y., \& Singh, D. (2017). Marketing Mix, Customer Satisfaction and Loyalty: An Empirical Study of Telecom Sector in Bhutan. Indian Journal of Commerce \& Management Studies, 8(2), 121-129.

Vlaev, I., Chater, N., Lewis, R., \& Davies, G. (2009). Reason-based judgments: Using reasons to decouple perceived price-quality correlation. Journal of Economic Psychology, 30(5), 721-731.

Sikandar Ali Qalati, born in 1986 in a small city of Sindh province named Sukkur, located in Pakistan. He did MBA in marketing from Sukkur IBA University, Sukkur, Sindh, Pakistan. Currently doing PhD in Jiangsu University, Jingkou, Zhenjiang, Jiangsu, P.R. China in marketing.

Sikandar Ali Qalati, born in 1986 in a small city of Sindh province named Sukkur, located in Pakistan. He did MBA in marketing from Sukkur IBA University, Sukkur, Sindh, Pakistan. Currently doing PhD in Jiangsu University, Jingkou, Zhenjiang, Jiangsu, P.R. China in marketing. 